\title{
Empowerment of People with Disabilities through the Establishment of Joint Ventures and Entrepreneurship Training in Banjar City
}

\author{
Riza Faizal ${ }^{1}$, Hasan Fahmi Kusnandar², Maman Sulaeman ${ }^{3}$ \\ ${ }^{1,2,3}$ Politeknik Triguna Tasikmalaya, Indonesia \\ mansulaeman1274@gmail.com
}

\section{Abstract}

The issue of disabilities is an always hot topic to be discussed not only in developing countries but also in developed countries. This is because groups with disabilities are a minority group whose fulfillment of their rights by the State often go unnoticed. Various efforts have been made by the central and local governments so that every element of society can be empowered in accordance with existing rules, but those efforts do not run smoothly, so that every program that aims to empower the community, as if it becomes a program that is normatively able to be treated with minimal. The purpose of this research is to analyze the empowerment of people with disabilities through the establishment of joint ventures and entrepreneurship training in Banjar City. The research method used is causality by analyzing the relationship between the phenomena examined. The population of this study is disability in Banjar City of 139 people and the determination of samples is carried out in a census. The results showed that the formation of joint ventures and entrepreneurial training can empower people with disabilities, in this case people with disabilities have business and income.

Keywords

dishability, income;

entrepreneurship; joint ventures

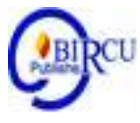

\section{Introduction}

People with disabilities still do not get the equivalent rights of other citizens to participate in development in Indonesia, even though a number of policies have been ratified and enacted such as Law No. 8 of 2016 on Persons with Disabilities and Law of the Republic of Indonesia Number 19 Year 2011 on ratification of the Convention on The Rights of Persons with Disabilities. The existence of Law No. 6 of 2014 on Villages also emphasizes the importance of meeting the needs of disable to the lowest government level, namely villages. The amount of village funds reaching 1.7 billion per year needs to be allocated to meet the needs of the disable. Efforts to build inclusion villages are indispensable due to the fact that more than 70,000 villages exist in Indonesia where people with disabilities live mostly and discrimination against people with disabilities is not clearly seen in the village. One of the important components in realizing the village of inclusion is the strengthening and empowerment of people with disabilities.

The rolling of empowerment programs for the poor today is inseparable from the various strategies and approaches used in empowerment, one of which is by the establishment of joint venture groups and entrepreneurial training. With this mechanism, it is expected that the empowerment process for the poor no longer sees the target of empowerment as an object, but as a perpetrator or subject in development. The government has realized the Joint Venture Group (KUBE) program Banjar City Government 
implements community of welfare program through Social Service and Manpower as the implementer of KUBE program by providing business capital for Social Development Families (KBS) in accordance with what they need, but of course it must be in accordance with the skills or abilities of the KBS. Later it is expected that the kbs who have received the aid goods can maximize the assistance, and the results can be used to improve the level of social welfare. So that the kbs can live independently without constantly depending on government assistance, both from the central government and local governments. The running of the joint venture group program needs to be equipped with entrepreneurial training. Entrepreneurship training as the basic capital for women to increase their capacity as economy actors.

The results of research by Kuncoro et al (2016) of the joint venture group is a forum or place to share knowledge about the empowerment and creativity of citizens, as seen from the indicators of the increasing number of citizens who are willing to participate. In addition, the joint venture group is able to provide added value to all citizens in terms of improving their lives. Setyowati's research (2015) also showed that by empowering women through Berkah Lestari Group, women are able to show their participation in the public domain. From this group, they gained knowledge and experience about batik, marketing, and more income. To overcome this, policies related to the empowerment of groups with disabilities should be placed in an honorable position. Disguising measures of employment opportunities between groups with disabilities and groups without disabilities risks maintaining an expressive relationship with them.

\section{Review of Literatures}

Empowerment is the process of increasing the capacity of a person or group in making choices to perform the preferred action or output. Empowerment is a combination of two interconnected factors namely agency and opportunity structure. The agency is the ability of a person to make choices that mean something to him or her. While the structure of opportunity is various aspects that make a person can do something because of his ability to choose. Thus, empowerment can be interpreted as a situation in a situation when there is a balance of power relations, then a person who has adequate capacity is able to make effective choices and can benefit from various efforts / projects that seek to reduce inequality. The concept of women's empowerment is basically a new paradigm of development that further ampersates the properties of "people centered, participatory empowering sustainable". Although the understanding is different but still has the same goal. namely to build power, by encouraging, grouping joint ventures, and raising awareness of its potential, as well as efforts to develop it in a better direction. Community empowerment is not just to meet basic needs or provide mechanisms for prevention of further thought processes (Setyawati, 2011).

Adi in Saleh et al (2019) says community empowerment can also be seen as a program as well as a process. Empowerment is called a program when viewed from the stages. Empowerment as a process when empowerment is to go on all the time. According to Mawardi et al (2019) Community empowerment as an application of government programs requires full enthusiasm from the community itself so that they will make every effort to improve the quality of their human resources in a total and continuous manner. Many efforts have indeed been carried out by the government, one of which is by providing assistance which is directly channeled to remote villages to support village development and the development of local potentials that are undoubtedly empowered. 
In the study of disability, there are at least two main views that are still actively conflicting to date, namely medical models and social models. The medical model refers to the view that disability is a condition that shows imperfections in a person so he must be given adequate care in order to participate normally. On the other hand, the social model considers that it is the social environment that makes people with disabilities, especially through physical environments that do not accommodate the diversity of individuals (including people with disabilities). Neither the medical model nor the social model can essentially be used individually. In order to better address issues related to disability, a model is needed that accommodates as many aspects as possible related to disability. Irresponsible application of the medical model will lead to blaming the victim, namely the people with disabilities themselves.

\section{Research Methods}

This research is categorized as explanatory research, which aims to explain the causal relationship between variables through hypothesis testing. This research approach is a survey approach. This research will be conducted in Banjar City. The object in this study was disability. The variables used in the research are entrepreneurial training, the formation of joint venture groups as free variables and empowerment of disability. In this study using primary type data with interview method, namely data sourced from the results of answers to questionnaires or interviews conducted with materials related to this research. The data sources were obtained from the Central Statistics Agency of Banjar City, Journals and Previous Research, and literature related to this research. The population of this study is disability in Banjar City of 139 people and the determination of samples is carried out in a census.

\section{Results and Discussion}

To find out how much influence the group of joint ventures and entrepreneurial training, towards the empowerment of people with partial disability in Banjar City, used the structure of path analysis or track analysis. The complete causality relationship between the variables of the joint venture group and the entrepreneurial training towards the empowerment of people with disabilities can be described as follows:

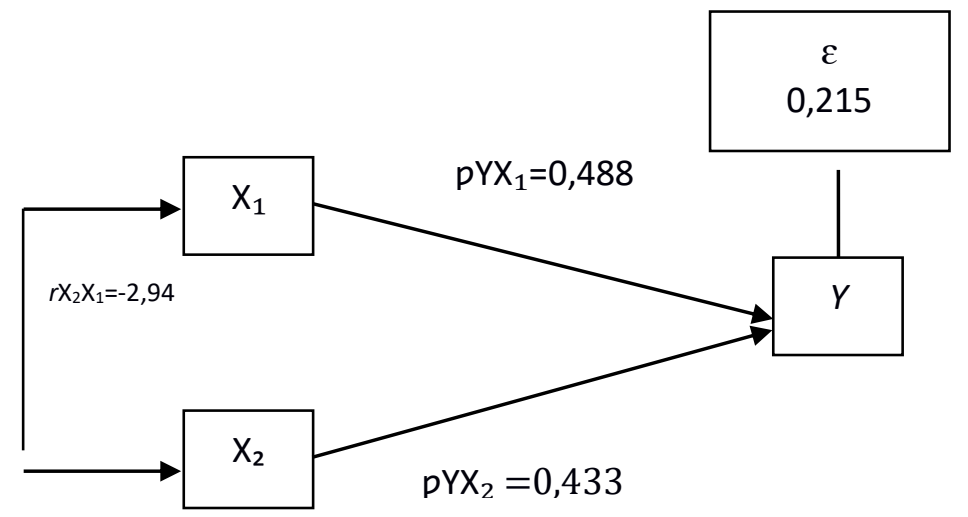

Figure 1. The structure of track analysis between the Group of joint ventures and entrepreneurial training on the empowerment of people with disabilities 
From Figure 1 above, it is known the value of the path coefficient between independent and dependent variables. The coefficient of the variable path of the joint venture group (X1) with the empowerment of people with disabilities ( $\rho$ YX1) is 0.488 . The coefficient value of the entrepreneurial training variable path (X2) with the empowerment of people with disabilities ( $\rho Y X 2$ ) of 0.433 and epsilon of 0.215 . From the coefficient value of the path in detail can be described as follows:

Table 1. Direct and indirect influences between research variables

\begin{tabular}{|c|c|}
\hline Description & Value \\
\hline The influence of $\mathrm{X} 1$ on Y directly $\left(\mathrm{pyx}_{1}\right)^{2}$ & 0,238 \\
\hline The influence of $\mathrm{X}_{1}$ on $\mathrm{Y}$ through $\mathrm{X}_{2} \mathrm{pyx}_{1 . \mathrm{X} 1 \mathrm{X} 2 \text {. } \mathrm{pyx}_{2}}$ & 0,180 \\
\hline The influence of Total $\mathbf{X}_{1}$ on $\mathbf{Y}$ & 0,418 \\
\hline The influence of X2 on Y directly $\left(\mathrm{pyx}_{2}\right)^{2}$ & 0,187 \\
\hline The influence of $\mathrm{X}_{2}$ on $\mathrm{Y}$ through $\mathrm{X}_{1} \mathrm{pyx}_{1 . \mathrm{X} 1 \mathrm{X} 2}$. $\mathrm{pyx}_{2}$ & 0,180 \\
\hline The influence of Total $\mathbf{X}_{2}$ on $\mathbf{Y}$ & $\mathbf{0 , 3 6 7}$ \\
\hline Simultaneous influence of $\mathrm{X} 1, \mathrm{X} 2$ on $\mathrm{Y}$ & $\mathbf{0 , 7 8 5}$ \\
\hline Influence of Other Variables & $\mathbf{0 , 2 1 5}$ \\
\hline
\end{tabular}

Based on table 1 above, it appears that: The influence of joint venture groups on the empowerment of disability is 0.418 or $41.8 \%$. The task against poverty is not the work of the Ministry of Social Affairs but all relevant ministries. However, the Ministry of Social Affairs is the leading sector. Some of the Ministry of Social Affairs programs related to poverty reduction and community empowerment are The Joint Venture Group (KUBe). The Joint Venture Group is a poor family group formed, growing, and developing on its initiative in implementing Productive Economic Enterprises (UEP) to increase family income and social welfare. Productive Economic Enterprises (UEP) is a social assistance provided to the Joint Venture Group (KUBe) to increase family income and social welfare.

The Joint Venture Group is a group of citizens or socially assisted families formed by citizens or socially assisted families that have been fostered through the process of Social Welfare Program (PROKESOS) activities to carry out social welfare activities and economic efforts in the spirit of togetherness as a means to improve the level of social welfare (Kemsos, 2019). KUBe is an integrated approach method and the entire PROKESOS process in order to establish the Poverty Reduction Program (MPMK). KUBe is not intended to replace the entire standard procedure of PROKESOS except for the Poor Social Welfare Assistance Program which covers the entire process. The formation of KUBe began with the process of forming groups as a result of social guidance and mentoring. KUBe's objectives are directed towards accelerating poverty reduction, through improving the ability to work together with KUBe members in groups, increasing revenue, business development, and increasing social awareness and solidarity among KUBe members and the surrounding community.

The results of this study support Hermuningsih's research (2015) shows that people's incomes increase thanks to the existence of KUBe and can develop the Business. Similarly, Haryati's research (2013) shows that KUBe is still an alternative program in poverty alleviation with a record of involving the community in planning. The results of Setyawati \& Suryono research (2019) showed that KUBe is able to improve entrepreneurial abilities in the form of the ability to manage strategies and take into account risks, creative abilities in Semin Village. This shows that KUBe is able to improve the economic capability of the community, especially very poor families.

Based on table 1 above, it is also seen that the influence of entrepreneurship training on the empowerment of dishability is 0.367 or $36.7 \%$. Entrepreneurship applies to everyone both 
for those who have normal physical conditions and those who have limitations / lack of physical conditions categorised in disability. Handling people with disabilities can not only be done in the orphanage, but also outside the orphanage. Oeh therefore the role of society is much needed. Of course, the success of economic empowerment efforts for people with disabilities can be achieved if some obstacles, among others, are the unavailable valid data, the lack of parental support, the lack of diversity of skills types, the diversity of conditions of people with disabilities, the lack of supporting facilities, the inadequacy of the ratio of educators and students, the lack of quality of teaching staff, lack of motivation for people with disabilities, low ability and courage of entrepreneurship, budget constraints, lack of networks, lack of sustainability. As well as the most important factors Tjahjanti, et al, Strategies To Help Disability Entrepreneurs To Empower... 39 predominantly supporting the success of economic empowerment for people with disabilities is the motivation of people with disabilities; family support; conformity between interests and capacities in the selection of fields taken; the existence of equipment and capital; the existence of assistance in both marketing and product development; the existence of a supportive network of work in the community; career development assistance institutions for people with disabilities entering the labor market. (Arni Surwanti \& Lela Hindasah,2013).

Research conducted by Prantasi Harmi Tjahjanti et al, 2017 is showing that many people with physical disabilities who live their needs with entrepreneurship, one of which is to make various kinds of pastries or wet. The obstacle they feel is related to physical limitations is in terms of stirring the cake dough. So that the cake dough machine is suitable for people with physical disabilities. The specific target is to make it easier for people with physical disabilities to do their daily work in relation to the field of entrepreneurship. So basically in order to prosper the social disability community, it must start from a disability environment since childhood. Improving social welfare for people with disabilities, among others, must be understood together that people with disabilities need recognition of their existence as individuals and social beings who have abilities and potentials that are not much different from normal people. They also need recognition and acceptance from parents, families and communities with disabilities. Children with disabilities can succeed in their lives if they get opportunities and support from parents. But what happens, there are still many parents who focus more on the shortcomings and ways of handling the child, compared to exploring the strengths that the child has. The role of the government for people with disabilities is not yet as expected, and people with disabilities also need public services / accessibility that can support all their activities and access to work according to their ability.

\section{Conclusion}

The results showed that the formation of joint ventures and entrepreneurial training can empower people with disabilities, in this case people with disabilities have business and income. Sustainable and sustainable economic empowering of disability entrepreneurs must be present, meaning that the state / government through cross-sectoral that involves all stakeholders to provide trainings, access to work and mentoring to entrepreneurs with disabilities. 


\section{Acknowledgements}

The author expresses his gratitude to the Director of Research and Community Service (DRPM) of the Ministry of Research and Technology/the National Research and Innovation Agency based on decree Number: 8/E1/KPT/2020 who has supported the implementation of this research by providing research grants for the Cooperation Research scheme between College to the author. The author also thanks the Head of the Region I Higher Education Service Institute and the chairman of the Institute for Research and Community Service based on the research contract number: 196/LL1/PG/2020 so that the author can carry out research well and the results of the author's research can be published in this paper.

\section{References}

Alma, B. 2011. Entrepreneurship. Bandung: Alfabeta.

Bachtiar, I. \& Jamaludin. 2011. Study of the Implementation Pattern of the Joint Venture Group (KUBe) and its Success Rate in Improving the Economy of the Village Poor. Proceedings of the National Seminar on Research and PKM science, technology, and health, p.117-124. Bandung: LPPM Universitas Islam Bandung.

Central Statistics Agency of Banjar City. 2020. Statistics of People's Welfare of Banjar City 2019. Banjar: BPS Banjar.

Central Statistics Agency. 2020. Poverty Data and Information 2018-2019. Jakarta: Central Statistics Agency.

Haryati, R. 2013. Poverty Management Policy through The Joint Venture Group (KUBe) (Electronic Version). Information, 18, 2:117-132.

Hermuningsih, S. 2015. Socio-Performance Development Model of Microfinance Institutions Joint Venture Group As An Effort to improve the Economic and Social Quality of People In The City of Yogyakarta. Bappeda Research Journal, Yogyakarta.

Cashmere. 2016. Entrepreneurship . 11th print. Jakarta: PT. King Grafindo Persada.

Mawardi, et al. (2019). Agenda Empowerment of People in Tarmizi Taher Point of View. Budapest International Research and Critics Institute-Journal (BIRCI-Journal). P. 443450.

Ministry of Social Affairs of the Republic of Indonesia. 2016. Guidelines for implementation of PKH Year 2016. Jakarta: Directorate General of Protection and Social Security.

Mulyani, E. 2009. Strategies to Foster Entrepreneurial Attitudes and Behaviors Through Entrepreneurial-Minded Cooperative Learning (Electronic Version). Journal of Economics and Education,

Ningsih, D.A.W.P. and Jember, I.M.. 2018. Effectiveness and Impact of Joint Venture Group Assistance Program (KUBe) on Target Household Income and Employment Opportunities (RTS) in Gianyar Regency. E-Journal of Development Economics Udayana University

Nurzaman, Retno Kurnia. 2017. The influence of entrepreneurial ability and creativity on the success of business at the restaurant sindang reret surapati branch of Bandung. Indonesian Computer University.

Paramita, I, A, P, U. 2017. Impact of The Joint Venture Group Program in economic empowerment of Families with Disabilities in Gianyar Regency. Jagaditha, 4,2,: 28-35.

Priadana, M. S. \& Thunder, E. F. 2010. Analysis of The Determining Factors of Success and Impact of The Joint Venture Group in West Java. Trionomics, 9,2:78-86. 
Saleh, A., et al. (2019). Development of Banking CSR Model for Community Empowerment Slum Area in Medan City. Budapest International Research and Critics Institute-Journal (BIRCI-Journal). P. 39-50.

Sariningsih, Y. 2018. Creativity and Innovation of Kube Actors. Polystyrene, 1.1: 13-37.

Setyawati, D\& Suryono, Y. 2015. The role of the Joint Venture Group (KUBE) in improving entrepreneurial skills in KUBE Manunggal Karep Semin Village, Semin, Gunungkidul, Yogyakarta. Journal of Out-of-School Education, Vol. 8, No. 6 of 2019.

Widayanti, S,Y,M \& Hidayatulloh, A,N. 2015. Joint Venture Group (KUBe) Performance in Poverty Alleviation. MCC Journal, 14.2.

Wulpiah, what's wrong with you? 2019. Implications for the implementation of The Joint Venture Group Progrsm (KUBe) on Economic Empowerment and Community Welfare in Bangka Regency. Scienta, Journal of Research Results, 4.1: 17- 